\title{
Analisis Berpikir Kreatif Siswa Berkemampuan Matematika Rendah Dalam Menyelesaikan Ill-Structured Problem
}

\author{
Maulana Al - Ghofiqi ${ }^{1}$, Santi Irawati ${ }^{1}$, Rustanto Rahardi ${ }^{1}$ \\ ${ }^{1}$ Pendidikan Matematika-Universitas Negeri Malang
}

\begin{tabular}{l}
\hline \hline INFO ARTIKEL \\
\hline Riwayat Artikel: \\
Diterima: 21-06-2019 \\
Disetujui: 22-10-2019 \\
\hline
\end{tabular}

\section{Kata kunci:}

creative thinking;

problem solving;

ill-structured problem;

low mathematical ability

berpikir kreatif;

penyelesaian masalah;

ill-structured problem;

kemampuan matematika rendah

\begin{abstract}
ABSTRAK
Abstract: The purpose of this study was to find out in detail the creative thinking of students with low mathematical abilities in solving ill-structured problems. This type of research is a case study, tconducted at SMPN 4 Waru (State Junior High School 4 Waru), Sidoarjo. 16 Students complete the ill-structured problem test, then subjects are chosen who have a level of creative thinking in the creative category and have low mathematical abilities. The results of the study showed students fulfilled the fluency aspect based on students' ability to provide at least two correct answers and were able to explain it. Flexibility aspects are fulfilled based on students' abilities in each answer written using different ideas. While the novelty aspect is not fulfilled because students do not give any unusual answers.
\end{abstract}

\begin{abstract}
Abstrak: Tujuan penelitian ini adalah untuk menganalisis berpikir kreatif siswa berkemampuan matematika rendah dalam menyelesaikan ill-structured problem. Jenis penelitian ini yaitu studi kasus, dilaksanakan di SMPN 4 Waru, Sidoarjo. 16 Siswa menyelesaikan tes ill-structured problem, selanjutnya dipilih subjek yang mempunyai level berpikir kreatif dalam kategori kreatif dan mempunyai kemampuan matematika rendah. Hasil penelitian menunjukkan siswa memenuhi aspek fluency berdasarkan kemampuan siswa dalam memberikan minimal dua jawaban benar serta mampu menjelaskannya. Aspek flexibility terpenuhi berdasarkan kemampuan siswa pada setiap jawaban yang dituliskan menggunakan ide yang berbeda, sedangkan aspek novelty tidak terpenuhi karena siswa tidak memberikan satu pun jawaban tidak biasa.
\end{abstract}

\author{
Alamat Korespondensi: \\ Maulana Al - Ghofiqi \\ Pendidikan Matematika \\ Universitas Negeri Malang \\ Jalan Semarang 5 Malang \\ E-mail: maulanaalghofiqi@gmail.com
}

Era globalisasi mendorong setiap individu mempunyai kemampuan dan keterampilan yang tinggi, salah satu keterampilan tersebut yaitu kreativitas. Kreativitas merupakan kompetensi kunci dalam pendidikan abad ke-21 (Lille \& Romero, 2017). Selain itu, kreativitas juga memainkan peran yang sangat penting dimana sebagian besar sistem pendidikan mendukung kreativitas sebagai kompetensi yang relevan untuk abad ke-21 (Trnova, 2014). Oleh karena itu, kreativitas dapat dikatakan suatu kompetensi yang perlu dicapai oleh siswa ketika melakukan kegiatan belajar mengajar di sekolah.

Ayllon, dkk (2016) menyatakan bahwa kreativitas masuk dalam bagian dari pendidikan matematika. Berdasarkan pendapat tersebut, maka aktivitas penyelesaian atau pemecahan masalah merupakan sarana untuk mengukur kreativitas siswa. Sriwongchai (2015) menyatakan bahwa sebagian besar guru dalam pembelajaran matematika tidak berkonsentrasi untuk meningkatkan berpikir kreatif, dan tidak menggunakan strategi untuk melibatkan pemikiran yang berbeda dari siswa. Hal ini seharusnya menjadi evaluasi untuk lebih memberi ruang gerak lebih kepada siswa untuk mengeksplor kreativitas melalui suatu masalah matematika. Katz \& Stupel (2015) berpendapat sebaiknya siswa diberi kesempatan untuk meningkatkan kreativitas matematis mereka dengan menggunakan tugas kreatif. Dapat disimpulkan bahwa kreativitas merupakan produk dari aktivitas berpikir untuk menyelesaikan atau memecahkan masalah dengan solusi berbeda yang dinamakan berpikir kreatif.

Silver (1997) mengemukakan bahwa aspek berpikir kreatif dalam pemecahan masalah tercermin dari tiga aspek, yaitu kefasihan (fluency), keluwesan (flexibility), dan kebaruan (novelty). Penjelasan dari tiga kompenen tersebut sebagai berikut, kefasihan (fluency) merupakan kemampuan siswa memberikan banyak jawaban yang benar sebagai penyelesaian masalah, keluwesan (flexibility) yaitu kemampuan siswa memberikan jawaban melalui beberapa ide atau cara yang berbeda, dan kebaruan (fluency) yaitu kemampuan siswa dalam menjawab dengan jawaban yang "tidak biasa" bagi siswa, yaitu jawaban yang dibuat siswa untuk pertama kalinya. Dapat disimpulkan ketika siswa melakukan aktivitas berpikir kreatif, diharapkan siswa mampu untuk memberikan jawaban yang memenuhi aspek kefasihan (fluency), keluwesan (flexibility), dan kebaruan 
(novelty) dalam menyelesaikan atau memecahkan masalah. Terkait dengan penyelesaian atau pemecahan masalah, tipe masalah yang diberikan dapat memberikan pengaruh terhadap kualitas jawaban siswa.

Pemberian masalah matematika kepada siswa seharusnya dapat mendorong siswa untuk memiliki keinginan yang kuat untuk dapat menyelesaikan masalah yang ada, terlebih lagi penyelesaian yang diinginkan yaitu penyelesaian dengan ide yang berbeda dan benar dengan kata lain penyelesaian yang kreatif. Arikan (2017) yang mengatakan setiap siswa harus termotivasi untuk berpikir kreatif sesuai dengan dirinya sendiri. Menindaklanjuti hal ini maka dibutuhkan suatu masalah matematika yang dapat menarik perhatian dan mempunyai karakteristik tertentu sehingga dapat mengeksplor lebih jauh mengenai kemampuan berpikir kreatif siswa. Terkait mengenai jenis masalah, Davidson \& Sternberg berpendapat bahwa masalah dapat dikategorikan menjadi dua yang beracuan suatu pertanyaan "apakah masalah tersebut memiliki arahan yang jelas untuk mencari soluisnya?", dimana pertanyaan tersebut mengarahkan mengenai tipe masalah yang ada. Masalah dengan arahan yang jelas dinamakan well-structured problems, sebaliknya masalah dengan tidak adanya ketidakjelasan mengenai arahan dalam menyelesaikannya dinamakan ill-structured problem (Sternberg, dkk, 2012). Dua tipe masalah tersebut akan berdampak pada redaksi soal yang diberikan. Shin, dkk mengatakan well-Structured problem merupakan masalah yang memiliki alur yang jelas untuk diselesaikan, dan masalah seperti ini dapat dikatakan dan dikategorikan masalah yang baik. Contoh dari wellstructured problem seperti berikut "Bagaimana menentukan luas jajar genjang?" dari masalah atau soal tersebut sudah jelas ketentuannya yaitu ditanyakan cara untuk menentukan luas suatu jajar genjang, berlawanan dengan itu, maka ill-structured problems sendiri didefinisikan merupakan masalah yang mempunyai alur yang tidak jelas untuk diselesaikan (Sternberg dkk., 2012). Alur yang tidak jelas pada Ill-structured problem membuat soal masalah ini tidak dapat diselesaikan hanya dengan prosedur pada umumnya.

Hong \& Kim (2016) mendefinisikan ill-structured problems melalui penjabaran beberapa sifat yang meliputi (1) keaslian (authenticity), (2) kompleksitas (complexity), dan (3) keterbukaan (openness). Keaslian (authenticity) adalah permasalahan yang berhubungan dengan kehidupan nyata sehingga cukup relevan menambahkan informasi yang perlu untuk melengkapi situasi nyata. kompleksitas (complexity) adalah adanya suatu konsep, aturan, informasi dan prinsip yang tidak tentu untuk menyelesaikan masalah. Keterbukaan (openness) adalah ketentuan memerbolehkan untuk menuliskan berbagai tafsiran dalam menyelesaikan masalah dan memberikan alasan dari tafsiran tersebut. Sifat-sifat yang melekat pada ill-structured problem inilah yang semakin menunjukkan bahwa soal yang masuk dalam kategori ill-structured problems adalah soal yang perlu penanganan khusus dalam menyelesaikannya.

Pada hasil penelitian sebelumnya dikatakan ketika menyelesaikan ill-structured problem siswa menggunakan sebagian besar pengalaman dan pengetahuan mereka sebelumnya untuk mempermudah strategi menemukan solusi (Chen, 2009). Lebih lanjut, Chen mengatakan bahwa dalam penyelesaian ill-structured problem dapat diketahui secara mendalam mengenai proses, representasi masalah, solusi alternatif, dan argumen dari solusi yang telah dibuat. Berdasarkan hal tersebut, maka dapat memberikan informasi secara detail mengenai ide atau gagasan kreatif siswa dalam menyelesaikan ill-structured problem.

Sebelumnya, peneliti melakukan studi pendahuluan terkait pemberian soal ill-structured problem untuk melihat ketercapaian berpikir kreatif oleh siswa. Soal ini diberikan kepada delapan orang siswa dengan kemampuan matematika yang bervariasi. Hasilnya menunujukkan $100 \%$ siswa memenuhi aspek kefasihan (fluency), 100\% siswa memenuhi aspek keluwesan (flexibility), dan 12,5\% siswa memenuhi aspek kebaruan (novelty). Berdasarkan hasil tersebut dapat disimpulkan bahwa soal ill-structured problem dapat memunculkan setiap aspek yang ada dalam berpikir kreatif.

Namun, pada penelitian sebelumnya, Krisanawati (2012) menyatakan bahwa siswa dengan kemampuan matematika rendah teridentifikasi berpikir kreatifnya berada pada level 0 (tidak kreatif). Hal ini cukup menarik perhatian peneliti karena berbeda dengan hasil studi pendahuluan yang dilakukan sebelumnya. Peneliti menduga siswa dengan kemampaun matematika rendah masih mempunyai peluang untuk dapat berpikir kreatif pada level yang lebih baik dalam menyelesaikan soal illstructured problem.

\section{METODE}

Penelitian ini termasuk dalam penelitian deskriptif kualitatif. Data yang dihasilkan dalam penelitian yakni berupa kalimat yang mendeskripsikan subjek. Strauss \& Corbin (2003) menjelaskan mengenai manfaat dari penelitian kualitatif, dimana fenomena yang kompleks dan sulit diungkap oleh penelitian kuantitatif akan lebih bisa diketahui secara detail dengan penelitian kualitatif ini. Selain itu, Penelitian kualitatif juga berperan mengeksplorasi fenomena pendidikan siswa yang lebih mendalam (Creswell, 2012). Penelitain ini bertujuan untuk mengetahui lebih detail mengenai ketercapain berpikir kreatif siswa berkemampuan matematika rendah dalam menyelesaikan ill-structured problem. Kemampuan berpikir kreatifmya akan didapat dari lembar jawaban Test Ill-Structured Problem (TISP). Selanjutnya, untuk mengklarifikasi dan merefleksi jawaban siswa akan ditelusuri pada tahap waancara, sedangkan kemapuan matematika siswa diketahui dari nilai tengah semester yang diberikan guru mata pelajaran matematika.

Peneliti melibatkan sebanyak 16 siswa kelas VIII SMPN 4 Waru, Siodarjo. Keenambelas siswa tersebut diberikan Test Ill-Structured Problem (TISP) dengan jumlah dua butir soal. Berikut adalah soal Ill-Structured Poblem (ISP) yang diberikan ke siswa untuk melihat kemampuan berpikir kreatifnya. 
1. Pak Budi ingin membuat taman di belakang rumahnya, salah satu sisi dari taman tersebut diketahui panjangnya $8 \mathrm{~m}$ dan mempunyai keliling $36 \mathrm{~m}$. Syarat lain yang perlu diperhatikan yaitu setiap desain bentuk taman harus mempunyai bentuk yang berbeda satu sama lain. Bantu Pak Budi untuk membuat paling sedikit 2 desain bentuk taman tersebut!

2. Aldo adalah salah satu anggota OSIS, dia ditugaskan oleh Ketua OSIS untuk membuat contoh desain majalah dinding (mading) berbentuk bangun datar dengan luas 10.000 $\mathrm{cm}^{2}$ setiap madingnya. Syarat lain yang harus diperhatikan Aldo ialah setiap desain mading yang dibuat harus mempunyai bentuk yang berbeda satu sama lain. Bantu Aldo untuk membuat desain mading paling sedikit 2 bentuk dengan syarat yang sudah ditentukan!

Hasil Test Ill-Structured Problem (TISP) menunjukkan bahwa ada beberapa siswa dengan kemampuan matematika rendah, dapat mencapai tingkat berpikir kreatif pada kategori cukup kreatif sampai kategori kreatif. Berdasarkan pertimbangan dari guru matematika di kelas tersebut terpilihlah subjek RAS dengan kemampuan matematika rendah yang dapat mencapai tingkat berpikir kreatif pada kategori kreatif.

\section{HASIL}

Berikut akan dipaparan hasil analisis berpiikir kreatif RAS dalam menyelesaikan Test Ill-Structured Problem (TISP) dengan jumlah dua butir soal. Beriku ini adalah jawaban yang dituliskan RAS pada lembar jawaban TISP.

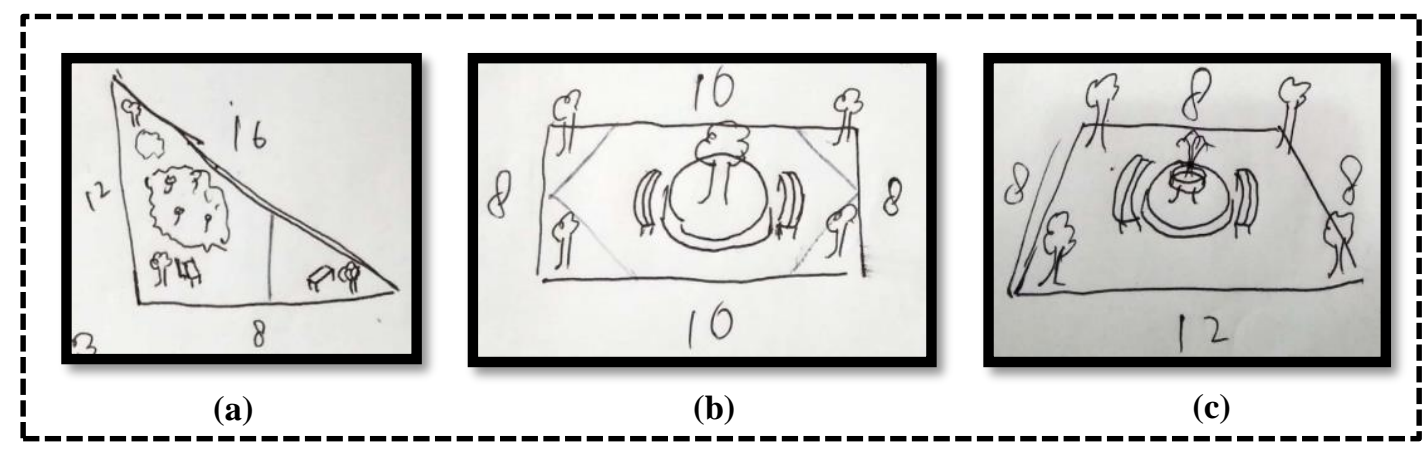

Gambar 1. Jawaban RAS pada TISP soal nomor 1

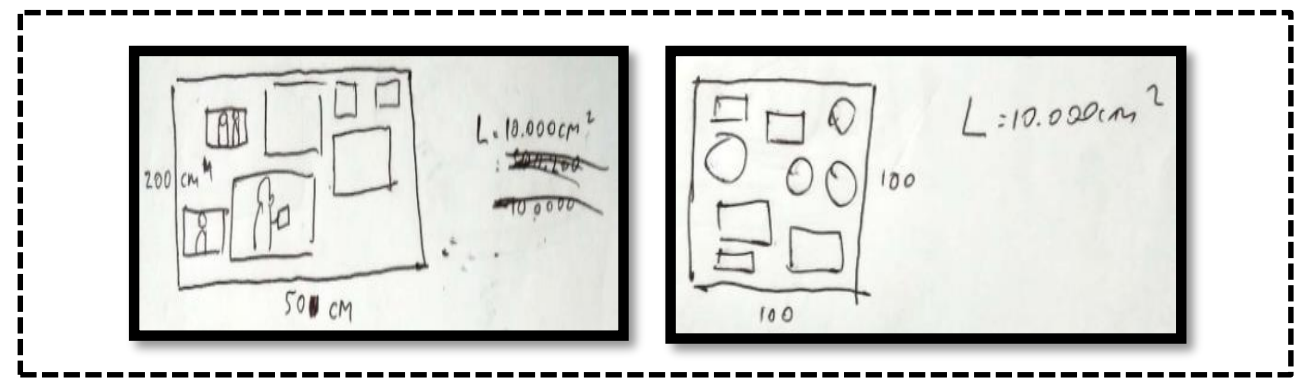

(a)

(b)

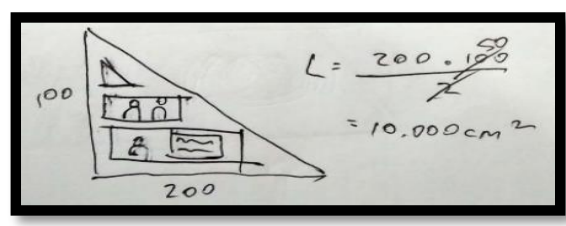

(c)

Gambar 2. Jawaban RAS pada TISP Soal Nomor 2 
Jawaban dari soal nomor 1 dan 2 yang dituliskan oleh RAS akan menggambarkan ketercapaian RAS terhadap aspekaspek berpikir kreatif, dimana hal tersebut diawali dengan penyekoran kualitatif dan analisis ketercapaian aspek berpikir kreatif. Berikut adalah hasil penyekoran kualitatif dan hasil ketercapaian berdasarkan hasil TISP yang dikerjakan oleh RAS pada soal nomor 1 dan 2 .

Tabel 1. Hasil Penyekoran Kualitatif Subjek RAS Sebelum Wawancara

\begin{tabular}{|c|c|c|c|c|c|c|c|c|}
\hline Subjek & \multicolumn{2}{|c|}{ Respons Siswa } & $\begin{array}{c}\text { Skor Aspek } \\
\text { Kefasihan } \\
\text { (Fluency) }\end{array}$ & $\begin{array}{l}\text { Skor Aspek } \\
\text { Keluwesan } \\
\text { (Flexibility) }\end{array}$ & $\begin{array}{c}\text { Skor Aspek } \\
\text { Kebaruan } \\
\text { (Novelty) }\end{array}$ & Total Skor & $\begin{array}{c}\text { Kategori } \\
\text { Ketercapaian }\end{array}$ & Keterangan \\
\hline \multirow[t]{2}{*}{ RAS } & Soal nomor 1 & $\begin{array}{l}\text { 3 Jawaban } \\
\text { benar: } \\
\text { Ide 1: bangun } \\
\text { datar segitiga } \\
\text { Ide 2: bangun } \\
\text { datar persegi } \\
\text { panjang } \\
\text { Ide 3: bangun } \\
\text { datar } \\
\text { trapesium }\end{array}$ & 2 & 3 & 0 & 5 & Kreatif & Kreatif \\
\hline & Soal nomor 2 & $\begin{array}{l}3 \text { jawaban } \\
\text { benar: } \\
\text { Ide 1: bangun } \\
\text { datar persegi } \\
\text { panjang } \\
\text { Ide } 2 \text { : bangun } \\
\text { datar persegi } \\
\text { Ide: bangun } \\
\text { datar segitiga }\end{array}$ & 2 & 3 & 0 & 5 & Kreatif & \\
\hline
\end{tabular}

Tabel 2. Hasil Ketercapaian Subjek RAS pada Aspek Berpikir Kreatif Sebelum Wawancara

\begin{tabular}{ccccccc}
\hline \multirow{2}{*}{ Butir soal } & \multicolumn{2}{c}{$\begin{array}{c}\text { Kefasihan } \\
\text { (Fluency) }\end{array}$} & $\begin{array}{c}\text { Keluwesan } \\
\text { (Flexibility) }\end{array}$ & \multicolumn{2}{c}{$\begin{array}{c}\text { Kebaruan } \\
\text { (Novelty) }\end{array}$} \\
\cline { 2 - 7 } & Skor & Ketercapaian & Skor & Ketercapaian & Skor & Ketercapaian \\
\hline 1 & 2 & $\checkmark$ & 3 & $\checkmark$ & 0 & - \\
2 & 2 & $\checkmark$ & 3 & $\checkmark$ & 0 & - \\
\hline
\end{tabular}

\section{Aspek Kefasihan (Fluency)}

Pada jawaban soal nomor 1, RAS mampu memberikan tiga jawaban benar. Jawaban pertama membuat desain taman berbentuk segitiga, kedua membuat desain taman berbentuk presegi panjang, ketiga membuat desain taman berbentuk trapesium (Gambar 1). Berdasarkan ketiga jawaban tersebut, RAS dapat dikatakan memenuhi aspek kefasihan (fluency), namun untuk memperkuat justifikasi tersebut maka akan telusuri lebih dalam mengenai pemahaman RAS terhadap jawaban yang telah dituliskan.

Berdasarkan hasil wawancara di atas, diketahui pemahaman RAS terhadap jawaban yang telah dituliskannya. Pada jawaban yang pertama ternyata maksud RAS yaitu membuat desain taman berbentuk segitiga siku-siku (Gambar 1a), tetapi sayangnya ukuran yang dibuat oleh RAS tidak sesuai dengan aturan pada segitiga siku-siku, satelah dikonfirmasi mengenai hal tersebut RAS terlihat kurang memahami konsep phytagoras pada segitiga siku-siku, maka dapat disimpulkan untuk jawaban yang pertama kurang benar. Selanjutnya pada jawaban kedua, terlihat jika RAS memahami konsep keliling pada persegi panjang sehingga RAS menentukan ukuran dua pasang sisi pada persegi panjang, dengan salah satu panjangnya yaitu 8 m, karena dia sadar itu merupakan syarat yang sudah ditentukan (Gambar 1b). Kemudian untuk jawaban ketiga, RAS juga bisa menjelaskan bagaimana dia menentukan ukuran pada desain taman berbentuk trapesium (Gambar 1c).

Setelah melakukan analisis dari jawaban tertulis pada lembara jawaban TISP dan jawaban lisan pada wawancara, untuk soal nomor 1 ini RAS masih dikategorikan memenuhi aspek kefasihan (fluency) karena masih dapat memberikan dua jawaban benar serta mampu menjelaskan dengan benar apa yang dituliskan. Selanjutnya, memperkuat kesimpulan RAS dapat dikatakan memenuhi aspek kefasihan (fluency) maka akan dilakukan analisis lanjutan pada jawaban soal nomor 2 (Gambar 2). 
Pada jawaban soal nomor 2, RAS mampu memberikan jawaban 3 jawaban benar. Jawaban pertama, RAS membuat mading berbentuk persegi panjang (Gambar 2a), mading yang kedua berbentuk persegi (Gambar 2b) dan mading yang ketiga berbentuk segitiga siku-siku (Gambar 2c). Jika diperhatikan dari ketiga bentuk mading yang dibuat secara ukurannya sudah benar dan memenuhi syarat yang ditentukan, maka RAS memenuhi aspek kefasihan (fluency). Kemudian untuk lebih meyakinkan penilaian awal, peneliti melakukan wawancara sebagai media untuk melihat pemahaman RAS terhadap jawaban yang sudah dituliskan.

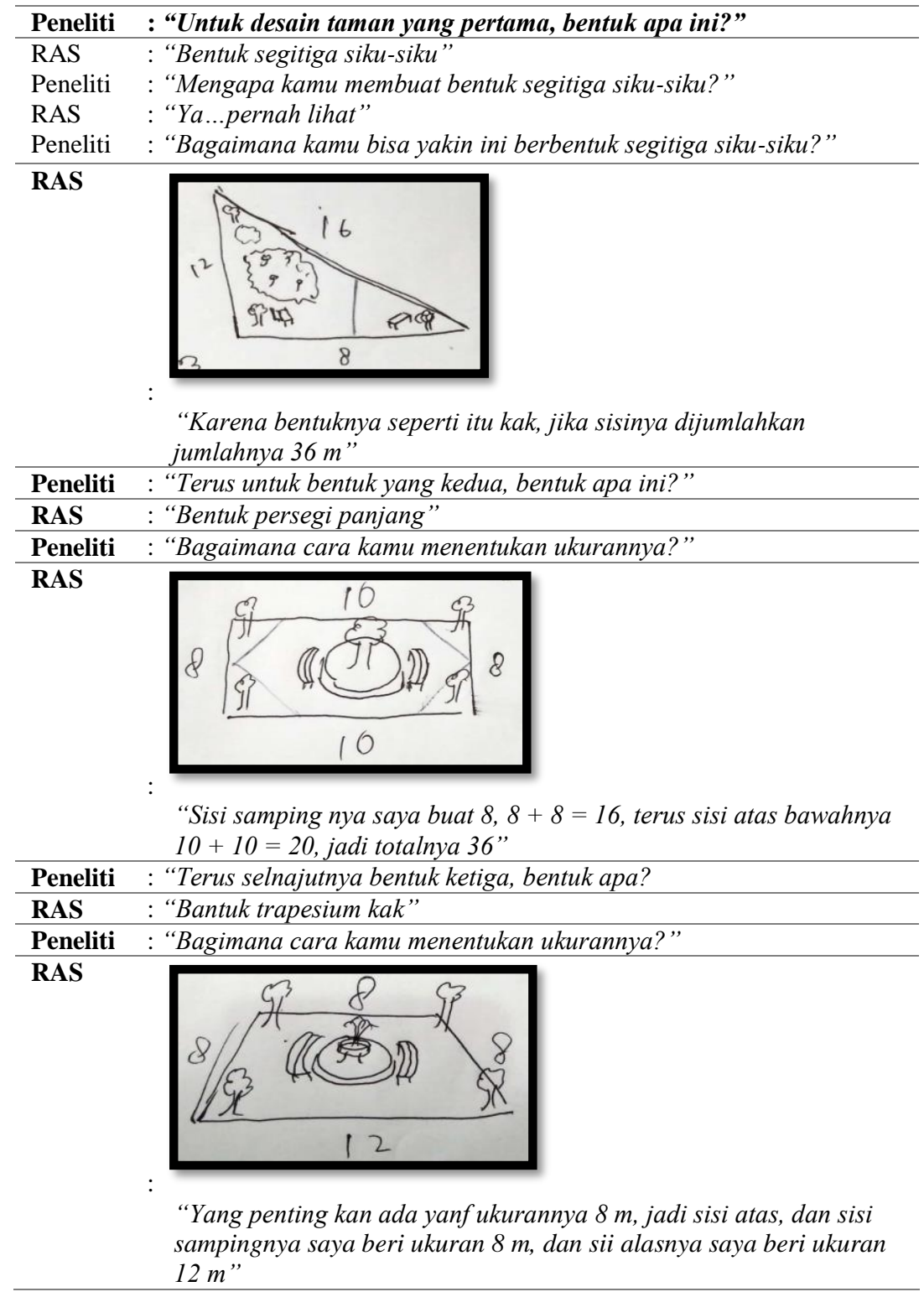




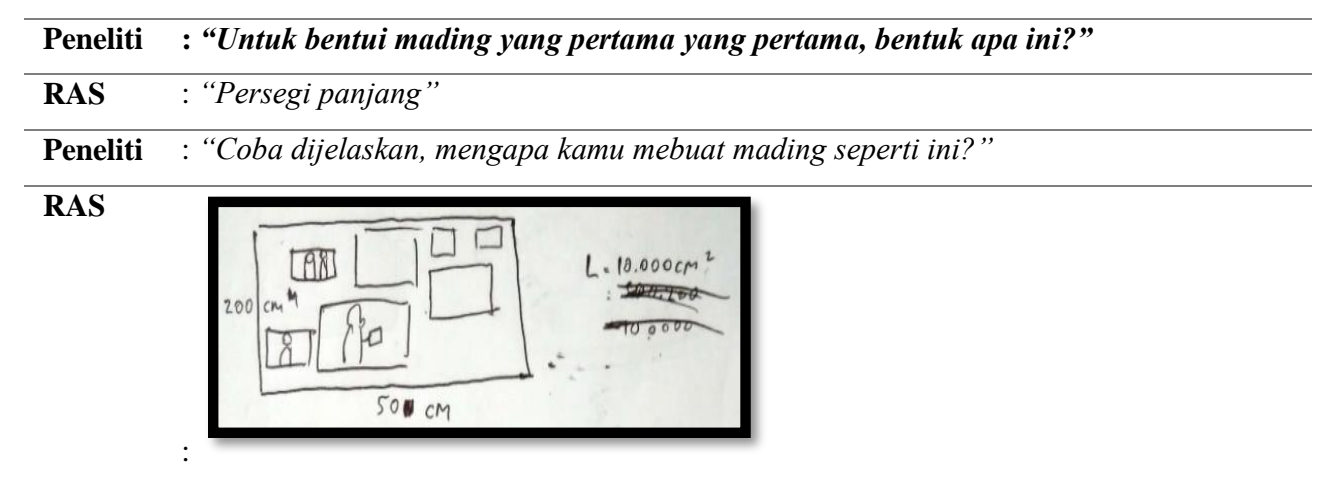

"Ya ini kan, harus mempunyai luas $10.000 \mathrm{~cm}^{2}$, ya langusng saya buat bentuk persegi panjang, $200 \times 50$, kan hasilnya 10.000"

\begin{tabular}{ll}
\hline Peneliti & $:$ "200 sebagai apanya mading?" \\
\hline RAS & $:$ "Panjangnya" \\
\hline Peneliti & $:$ "Kalau 50 sebagai apanya?" \\
\hline RAS & $:$ "Lebarnya kak" \\
\hline Peneliti & $:$ "Oke, Untuk mading yang kedua berbentuk apa?" \\
\hline RAS & $:$ "Persegi kak" \\
\hline PASeliti & $:$ "Coba jelaskan bagaimana kamu menentukan ukurannya?"
\end{tabular}

"Langsung saya buat ukuran $100 \times 100=10000 \mathrm{~cm}^{2} "$

\begin{tabular}{ll}
\hline Peneliti & $:$ "Selanjutnya, untuk mading yang ketiga, berbentuk apa?" \\
\hline RAS & $:$ "Segitiga siku-siku kak" \\
\hline Peneliti & $:$ "Bagaimana cara kamu menentukan ukurannya?”
\end{tabular}

"Ya, $100 \times 200$ dibagi 2 hasilnya $10000 \mathrm{~cm}^{2} "$

Setelah melihat hasil wawancara di atas, menggambarkan bahwa RAS paham mengenai bentuk mading yang dia buat dan paham mengenai konsep luas bangun datar yang menjadi ide dalam membuat mading. Berdasarkan uraian hasil analisis aspek kefasihan (fluency) pada subjek RAS, dimana pada analisis tersebut terjadi kekonsistenan data antara hasil jawaban tertulis pada lembar jawaban TISP nomor 1 dan nomor 2 (Gambar 1 dan 2) dengan jawaban lisan pada tahap wawancara. Maka, dapat disimpulkan bahwa RAS memenuhi aspek kefasihan (fluency) pada berpikir kreatif. 


\section{Aspek Keluwesan (Flexibility)}

Pada jawaban soal nomor 1 (Gambar 1), terlihat RAS mampu menjawab sebanyak tiga desain taman, dengan setiap desain taman menggunaka ide yang berbeda pula, jadi RAS menggunakan tiga ide berbeda. Ide pertama menggunakan ide bangun datar segitiga siku-siku namun, berdasar pada hasil wawancara pada aspek kebaruan (fluency) pada ide segitiga ini RAS kurang memahami teorema pythagoras pada segitiga siku-siku yang mengakibatkan desain taman yang dibuat ukurannya tidak sesuai. Ide yang kedua menggunakan ide bangun persegi panjang, dan berdasar pada hasil wawancara pada aspek kebaruan (fluency) RAS paham mengenai konsep dasar keliling pada bangun persegi panjang sehinggga RAS dapat menentukan ukuran desain taman berbentuk persegi panjang dengan benar. Ide yang ketiga menggunakan ide bangun datar trapesium, dan berdasar pada hasil wawancara pada aspek kebaruan (fluency) RAS juga paham mengenai konsep keliling pada trapesium sehingga RAS dapat menentukan ukuran desain taman berbentuk trapesium dengan benar.

Setelah melihat analisis tersebut dapat dikatakan RAS memenuhi aspek keluwesan yaitu mampu memberikan ide yang berbeda pada setiap jawaban yang dituliskan. Namun sayangnya, pada tahap wawancara ketika membahas soal nomor 1, RAS tidak memberikan ide tambahan lagi seperti berikut.

\begin{tabular}{ll}
\hline Peneliti & : “Apakah ada pandangan bentuk lain selain desain taman yang sudah kamu buat?” \\
\hline RAS & $:$ "Tidak ada kak”
\end{tabular}

Namun demikian, RAS tetap dapat dikatakan memenuhi aspek keluwesan (flexibility), karena ada tahap TISP RAS sudah mampu menggunakan tiga ide yang berbeda. Selanjutnya, untuk lebih meyakinkan lagi menyimpulkan RAS memenuhi aspek keluwesan (flexibility), maka akan dianalisis pula jawaban RAS pada soal nomor 2.

Pada jawaban soal nomor 2, RAS mampu memberikan tiga jawaban bentuk mading, dan setiap bentuk mading menggunakan ide yang berbeda. Ide yang pertama, RAS membuat bentuk mading dengan menggunakan ide bangun datar persegi panjang (Gambar 2a). Ide yang kedua, RAS membuat bentuk mading dengan menggunakan ide bangun datar persegi (Gambar 2b). Ide yang ketiga, RAS membuat bentuk mading dengan menggunakan ide bangun datar segitiga siku-siku (Gambar 2c). Pada setiap ide yang diberikan RAS untuk menjawab soal nomor 2, RAS mampu menjelaskan bagaimana dia menentukan ukuran bentuk mading pada setiap ide yang dia gunakan. Selanjutnya, pada tahap wawancara sama halnya seperti soal nomor 1, RAS tidak memberikan tambahan ide untuk membuat bentuk mading yang lain. Namun, terlepas dari itu, untuk soal nomor 2 ini RAS tetap dapat dikatakan memenuhi aspek keluwesan (flexibility) karena pada tahap TISP sudah mampu mmberikan ide yang berbeda pada setiap jawaban pada soal nomor 2 .

Berdasarkan uraian hasil analisis aspek keluwesan (flexibility) pada subjek RAS, dimana pada analisis tersebut terjadi kekonsistenan data antara hasil jawaban tertulis pada lembar jawaban TISP nomor 1 dan nomor 2 (Gambar 1 dan 2) dengan jawaban lisan pada tahap wawancara. Maka, dapat disimpulkan bahwa RAS memenuhi aspek keluwesan (flexibility) pada berpikir kreatif.

\section{Aspek Kebaruan (Novelty)}

Pada jawaban soal nomor 1 (Gambar 1), terlihat bahwa tidak ada jawaban yang masuk dalam kategori tidak biasa yaitu jawaban yang berbeda dengan jawaban di buku maupun jawaban yang berbeda dengan jawaban teman sebayanya. Jawaban pada nomor 1, RAS hanya menggunakan ide yang terdiri dari satu bangun datar saja tidak ada gabungan bangun datar ataupun bangun datar yang dimodifikasi. Pada tahap wawancara, ketika RAS ditanyakan pandangan lain terkait desain taman, RAS terlihat sudah puas dengan jawaban yang sudah dituliskan sebelumnya. Jadi, dapat disimpulkan untuk jawaban soal nomor 1, RAS tidak memenuhi aspek kebaruan (novelty).

Selanjutnya, pada jawaban soal nomor 2 (Gambar 2) tidak terlihat juga jawaban yang masuk dalam kategori tidak biasa. RAS mampu memberikan tiga bentuk mading yang berbeda dengan setiap masing menggunakan ide yang beda pula, tetapi sayangnya di antara 3 ide tersebut tidak yang masuk dalam kategori jawaban tidak biasa. Sama halnya dengan soal nomor 1, pada soal nomor 2, RAS juga sepertinya sudah puas dengan jawaban yang sudah dia tuliskan, ketika ditayai mengenai pandangan bentuk lain RAS menjawab tidak ada. Jadi, pada soal nomor dua ini juga RAS disimpulkan tidak dapat memenuhi aspek kebaruan (novelty).

Berdasarkan uraian hasil analisis aspek kebaruan (novelty) pada subjek RAS, dimana pada analisis tersebut terjadi kekonsistenan data antara hasil jawaban tertulis pada lembar jawaban TISP nomor 1 dan nomor 2 (Gambar 1 dan 2) dengan jawaban lisan pada tahap wawancara. Maka, dapat disimpulkan bahwa RAS tidak dapat memenuhi aspek kebaruan (novelty) pada berpikir kreatif. Setelah menganalisis jawaban dari EDS berupa tulisan maupun lisan dari hasil wawancara, maka berikut ini adalah ketercapaian subjek EDS pada berpikir kreatif yang sudah diperbarui sesuai hasil wawancara dan analisis. 
Tabel 3. Hasil Penyekoran Kualitatif Subjek RAS Sesuai Hasil Wawancara dan Analisis

\begin{tabular}{|c|c|c|c|c|c|c|c|c|}
\hline Subjek & \multicolumn{2}{|c|}{ Respons Siswa } & \multirow{2}{*}{$\begin{array}{c}\text { Skor Aspek } \\
\text { Kefasihan } \\
\text { (Fluency) }\end{array}$} & \multirow{2}{*}{$\begin{array}{c}\text { Skor Aspek } \\
\text { Keluwesan } \\
\text { (Flexibility) }\end{array}$} & \multirow{2}{*}{$\begin{array}{c}\text { Skor Aspek } \\
\text { Kebaruan } \\
\text { (Novelty) } \\
0\end{array}$} & \multirow{2}{*}{$\begin{array}{c}\text { Total } \\
\text { Skor } \\
4\end{array}$} & \multirow{2}{*}{$\begin{array}{c}\text { Kategori } \\
\text { Ketercapaian } \\
\text { Kreatif }\end{array}$} & \multirow{2}{*}{$\begin{array}{c}\text { Keterangan } \\
\text { Kreatif }\end{array}$} \\
\hline & Soal nomor 1 & $\begin{array}{l}3 \text { Jawaban benar: } \\
\text { Ide } 1 \text { : bangun } \\
\text { datar segitiga } \\
\text { Ide } 2 \text { : bangun } \\
\text { datar persegi } \\
\text { panjang } \\
\text { Ide } 3 \text { : bangun } \\
\text { datar trapesium }\end{array}$ & & & & & & \\
\hline RAS & Soal nomor 2 & $\begin{array}{l}3 \text { jawaban benar: } \\
\text { Ide } 1 \text { : bangun } \\
\text { datar persegi } \\
\text { panjang } \\
\text { Ide } 2 \text { : bangun } \\
\text { datar persegi } \\
\text { Ide: bangun datar } \\
\text { segitiga }\end{array}$ & 2 & 3 & 0 & 5 & Kreatif & \\
\hline
\end{tabular}

Tabel 4. Hasil Ketercapaian Subjek RAS pada Aspek Berpikir Kreatif Sesuai Hasil Wawancara dan Analisis

\begin{tabular}{ccccccc}
\hline Butir soal & \multicolumn{2}{c}{$\begin{array}{c}\text { Kefasihan } \\
\text { (Fluency) }\end{array}$} & Keluwesan (Flexibility) & $\begin{array}{c}\text { Kebaruan } \\
\text { (Novelty) }\end{array}$ \\
\cline { 2 - 6 } & Skor & Ketercapaian & Skor & Ketercapaian & Skor & Ketercapaian \\
\hline 1. & 1 & $\checkmark$ & 3 & $\checkmark$ & 0 & - \\
2. & 2 & $\checkmark$ & 3 & $\checkmark$ & 0 & -
\end{tabular}

Kemudian, dapat dibuat kesimpulan bahwa subjek RAS memenuhi dua aspek, yaitu aspek kefasihan (fluency) dan keluwesan (flexibility) sehingga dalam kategori pelevelan berpikir kreatif RAS masuk dalam level 3 yaitu kategori kreatif. Selanjutnya, mengacu pada tabel penyekoran (Tabel 3) tabel ketercapaian (Tabel 4) subjek RAS ini dapat dikatakan dominan pada aspek kefasihan (fluency) dan aspek keluwesan (flexibility), yang berarti RAS ini mampu memberikan banyak jawaban dengan setiap jawaban dengan ide yang berbeda berbeda-beda, namun pada ide yang digunakan belum ada ide yang masuk dalam kategori tidak biasa, sehingga aspek kebaruannya (novelty) belum bisa terpenuhi.

\section{PEMBAHASAN}

Pada paparan hasil, telah diketahui bahwa RAS memenuhi dua aspek dalam berpikir kreatif, yaitu aspek kefasihan (fluency) dan keluwesan (flexibility) yang berarti RAS mencapai level berpikir kreatif pada kategori kreatif. Berikut adalah pembahasan terkait analisis berpikir kreatif RAS dalam menyelesaikan ill-structured problem.

\section{Kefasihan (fluency)}

Pada Test Ill-Structured Problem (TISP) nomor 1, RAS mampu membuat empat desain taman dan mampu menjelaskan dengan baik cara dia menentukan ukuran keliling pada setiap desain taman yang dibuat. Pada nomor 2, RAS mampu membuat tiga bentuk mading dan mampu menjelaskan cara menentukan ukuran pada setiap bentuk mading yang dibuat. Kedua hal tersebut selaras dengan pendapat Sriraman, dkk (2013) yang mengatakan kefasihan merupakan kelancaran dalam memberikan solusi terhadap masalah yang diberikan, dengan begitu dapat dikatakan RAS memenuhi aspek kefasihan (fluency) dalam berpikir kreatif.

Sejalan dengan uraian sebelumnya, dalam menyelesaikan tes ill-structured problem (TISP) RAS mampu membuat desain taman dan bentuk mading sesuai pengetahuan yang mereka terkait bentuk taman serta cara menentukan keliling pada taman dan luas pada mading. Hal menunjukkan kesesuaian dengan salah satu sifat yang ada dalam ill-structured problem yaitu keterbukaan (openness) dimana adanya kesempatan pada siswa untuk menuliskan berbagai tafsiran dalam menyelesaikan masalah (Hong \& Kim, 2016). 


\section{Keluwesan (flexibility)}

Ketika menyelesaikan Test Ill-Structured Problem (TISP), soal nomor 1 RAS mampu menyelesaikan masalah dengan cara membuat desain taman menggunakan dua ide bangun datar yang berbeda, meliputi (1) persegi panjang dan (2) trapesium, sehingga dapat dikatakan RAS menyelesaikan soal nomor 1 dengan menggunakan ide yang berbeda-beda. Pada soal nomor 2, RAS mampu menyelesaikan masalah dengan cara membuat bentuk mading menggunakan empat ide bangun datar yang berbeda meliputi (1) persegi panjang, (2) persegi, dan (3) segitiga siku-siku, sehingga dapat dikatakan RAS menyelesaikan soal nomor 2 dengan menggunakan ide yang berbeda-beda. Hal ini sesuai pendapat Munandar (2002:168) yang mengatakan bahwa gagasan, jawaban, atau langkah-langkah penyelesaian yang berbeda-beda merupakan ketercapaian dari aspek keluwesan. Maka, dapat dikatakan EDS memenuhi aspek keluwesan (flexibility)

Sejalan dengan uraian di atas, dalam menyelesaikan tes ill-structured problem (TISP). RAS menyelesaikan masalah tersebut berdasar informasi yang ada di soal, sehingga perlu adanya menambahkan informasi secara subjektif untuk bisa menyelesaikan soal ill-structured problem tersebut. Hal ini sesuai dengan pengertian salah satu sifat yang melekat pada illstructured problem yaitu kompleksitas (complexity) yang merupakan adanya suatu konsep, aturan, informasi dan prinsip yang tidak tentu untuk menyelesaikan masalah (Hong \& Kim, 2016).

Namun, dalam menyelesaikan ill-structured problem, RAS tidak dapat memenuhi aspek kebaruan (novelty) yang berarti RAS tidak mampu memberikan atau menggunakan ide yang berasal dari modifikasi suatu ide ataupun penggabungan beberapa ide yang dalam penelitian ini disebut ide tidak biasa.

\section{SIMPULAN}

Berdasarkan uraian hasil di atas, dapat disimpulkan bahwa berpikir kreatif siswa berkemampuan matematika rendah ketika menyelesaikan ill-structured problem dapat memenuhi dua aspek berpikir kreatif yang meliputi aspek kefasihan (fluency) dan aspek keluwesan (flexibility). Hal itu menunjukan bahwa dengan diberikannya soal ill=structured problem siswa berkamampuan matematika rendah dapat lebih menunjukkan hal yang positif dalam penyelesaian masalah yaitu mampu memberikan banyak jawaban benar terkait soal yang diberikan dan pada setiap jawabannya menggunakan ide yang berbeda. Terkait dengan hal tersebut, maka dapat dikatakan masih sangat mungkin siswa berkemampuan matematika rendah dapat menunjukkan ketercapaian level berpikir kreatif pada kategori kreatif ketika siswa tersebut diberikan soal yang dapat mengeksplor lebih kemampuan berpikir kreatifnya salah satu yaitu soal dengan karakteristik ill-structured problem.

Terkait kesimpulan pada penelitian ini, ada beberapa saran yang diberikan peneliti. Pertama, untuk melatih kemampuan berpikir kreatif siswa dapat dibiasakan pemberian soal dengan karakteristik ill-structured problem. Kedua, masih sangat memungkinkan ada faktor lain yang memengaruhi kemampuan berpikir kreatif siswa, maka dari itu untuk penelitian selanjutnya mungkin dapat meneliti faktor apa saja yang memengaruhi kemampuan berpikir kreatif siswa selain kemampuan matematika.

\section{DAFTAR RUJUKAN}

Arikan, E. E. (2017). Is There a Relationship between Creativity and Mathematical Creativity? Journal of Education and Learning, 6(4), 239. https://doi.org/10.5539/jel.v6n4p239

Ayllón, M. F., Gómez, I. A., \& Ballesta-Claver, J. (2016). Pensamiento matemático y creatividad a través de la invención y resolución de problemas matemáticos. Propósitos y Representaciones, 4(1). https://doi.org/10.20511/pyr2016.v4n1.89

Chen, C.-H. (2009). Reframing Narrative Cases for Ill-Structured Contexts: The Design with Learners in Mind. Journal of Learning Design, 3(1), 34-40.

Creswell, J. W. (2012). Educational research: planning, conducting, and evaluating quantitative and qualitative research (4th ed). Boston: Pearson.

Hong, J. Y., \& Kim, M. K. (2016). Mathematical Abstraction in the Solving of Ill-Structured Problems by Elementary School Students in Korea. EURASIA Journal of Mathematics, Science \& Technology Education, 12(2), $267-281$. https://doi.org/10.12973/eurasia.2016.1204a

Katz, S., \& Stupel, M. (2015). Promoting Creativity and Self-efficacy of Elementary Students through a Collaborative Research Task in Mathematics: A Case Study. Journal of Curriculum and Teaching, 4(1). https://doi.org/10.5430/jct.v4n1p68

Krisanawati, E. (2012). Kreativitas Siswa Dalam Memecahkan Masalah Matematika Divergen Berdasarkan kemampuan matematika siswa. MATHdunesa, 1(1), 3.

Lille, B., \& Romero, M. (2017). Creativity Assessment in the Context of Maker-based Projects. Design and Technology Education: An International journal, 22(3), 32-47.

Munandar, U. S. C. (2002). Kreativitas dan Keberbakatan. Jakarta: Gramedia Pustaka.

Silver, E. A. (1997). Fostering Creativity through Instruction Rich in Mathematical Problem Solving and Problem Posing. Electronic Edition, 29(3). Diambil dari http://www.emis.de/journals/ZDM/zdm973a3.pdf

Sriraman, B., Haavold, P., \& Lee, K. (2013). Mathematical Creativity and Giftedness: A Commentary on and Review of Theory, New Operational Views, and Ways Forward. ZDM, 45(2), 215-225. https://doi.org/10.1007/s11858-013-0494-6 
1395 Jurnal Pendidikan, Vol. 4, No. 10, Bln Oktober, Thn 2019, Hal 1386-1395

Sriwongchai, A. (2015). Developing the Mathematics Learning Management Model for Improving Creative Thinking in Thailand. International Education Studies, 8(11), 77. https://doi.org/10.5539/ies.v8n11p77

Sternberg, R. J., Sternberg, K., \& Mio, J. S. (2012). Cognitive psychology (6th ed). Belmont, CA: Wadsworth/Cengage Learning.

Strauss, \& Corbin, j. (2003). Dasar-dasar Penelitian Kualitatif: Tata Langkah dan Teknik-teknik Teorisasi Data. Yogyakarta: Pustaka Pelajar.

Trnova, E. (2014). IBSE and Creativity Development. Science Education International, 25(1), 8-18. 